\title{
7 Verbs of emission
}

Verbs of emission are the second class of verbs that are discussed in detail with respect to verbal degree gradation. These verbs provide some interesting problems which will be highlighted during the following chapter. In 7.1, I will start with a general discussion of verbs of emission. The focus is on argument realization and a subclassification of verbs of emission. Degree gradation of each of the subclasses is separately discussed in the sections 7.2 to 7.5 .

\subsection{Emission verbs - a general perspective}

Verbs of emission form a semantic class of verbs in Levin's (1993) classification. The verbs of this class describe the emission of a substance or stimulus by an entity (Levin, 1993, 233). Depending on the type of substance/stimulus emitted, four different subclasses of emission verbs can be distinguished. The four relevant subtypes are sound emission, light emission, smell emission and substance emission (cf. (1) for examples of each subclass and see Levin (1993, 233ff.) for more English examples).

(1) a. Verbs of sound emission: beep, rattle, knock, jingle, ring

b. Verbs of light emission: blink, sparkle, gleam, glitter, glow

c. Verbs of smell emission: smell, stink

d. Verbs of substance emission: bleed, sweat, fester

A distinct class in Levin's (1993) lexical classification is the verbs of sounds made by animals, such as bark, grunt or yowl. As she mentions, some of these verbs also belong to the class of verbs of sound emission. I will not distinguish between them but subsume verbs of sounds made by animals under the label of verbs of sound emission. A further related, but somewhat different class of verbs is weather verbs such as hail, rain, thunder and snow. These verbs are used to describe weather phenomena which are related to 
the emission of a substance, a sound or light. Hence, at least some of these verbs are emission verbs. I take verbs such as snow, hail and rain as verbs of substance emission and a verb like thunder as a verb of sound emission.

Perlmutter $(1978,163)$ describes verbs of emission as unergatives that express a "non-voluntary emission of stimuli that impinge on the senses" (also Rappaport Hovav \& Levin 2000; Potashnik 2012). Basically, emission verbs are intransitive and the single argument is the emitter. The emitter argument denotes the entity that emits the respective stimulus or substance. This is illustrated in (2) for a verb of substance emission (a) and a verb of smell emission (b). Even if the emitter is animated, as in the sentences in (2), emission of blood or smell is a non-voluntary process.
a. Peter blutet.
Peter bleeds
'Peter is bleeding.'
b. Der Hund stinkt.
the dog stinks
'The dog stinks.'

As Rappaport Hovav \& Levin $(2000,280)$ further point out, the emitter argument is usually non-agentive and does not show control of the situation. The argument of verbs like bark, grunt and yowl is not a usual emitter as it has control of the situation and acts voluntarily. This indicates that nonvolitionality and lack of control are not defining properties for the semantic role 'emitter' as some emitters behave like agents.

Weather verbs differ from verbs of emission in having, at least in German and English, one syntactic argument but no semantic one (Van Valin \& LaPolla, 1997, 147). German requires an expletive pronoun in subject position (3) and no realization of an explicit emitter argument.
Es regnet.
it rains
'It is raining.'

Emission verbs are mainly used intransitively but there are some emission verbs that also license a transitive and thereby causative use. An example form German is the verb läuten 'ring' in (4). The subject is the causer of the emission, whereas the emitter is realized as direct object. 
(4) a. Die Glocke läutet.

the bell rings

'The bell is ringing.'

b. Der Küster läutet die Glocke.

the sexton rings the bell

'The sexton is ringing the bell.'

Transitive uses of verbs of emission are very restricted and there is some debate regarding the exact restrictions and how they are determined (see Levin \& Rappaport Hovav 1995 as well as Potashnik 2012 and the literature cited therein for this discussion). Many of the examples cited by Potashnik for English are not acceptable in German. For example, he mentions the sentence pairs The tea-cups clattered and I clattered the tea-cups (Potashnik, 2012, 263). As (5a) shows, the German verb klappern 'clatter' has the same intransitive use as its English equivalent but there is no direct transitive correspondent (b). Rather the emitter has to be realized in an instrumental-PP (c).

(5) a. Die Teetassen klapperten.

the tea.cups clattered

'The tea cups clattered.'

b. *Ich klapperte die Teetassen.

I clattered the tea.cups

c. Ich klapperte mit den Teetassen.

I clattered with the tea.cups

'I clattered the tea cups.'

This kind of argument alternation is restricted to verbs of sound emission (5) and verbs of light emission (6), in which case the emitter functions as a manipulatable device that can be used for sound or light production.

(6) a. Die Lampe leuchtet.

the lamp shines

'The lamp shines.'

b. Peter leuchtet mit einer Taschenlampe.

Peter shines with a torch.light

'Peter shines a torch light.'

c. *Peter leuchtet eine Taschenlampe.

Peter lights a torch.light 
If the emitter cannot be manipulated, it is not possible to introduce an effector (7). ${ }^{1}$ One cannot cause the sun to emit light hence it cannot be realized as an instrumental-PP in (7b).
a. Die Sonne scheint. the sun shines 'The sun shines.'
b. \#Peter scheint mit der Sonne. Peter shines with the sun

Verbs of substance as well as smell emission reject this kind of argument alternation, in which the emitter is demoted to direct object or oblique status and an effector argument is added in subject position. This is shown in (8) for the verb bluten 'bleed.' In (a) it is used with a non-agentive emitter argument, but as (b) and (c) show it is not possible to add an effector argument and to demote the emitter to be a direct object or oblique argument.
a. Die Wunde blutet.
the wound bleeds
'The wound is bleeding.'
b. "Peter blutet die Wunde.
Peter bleeds the wound
c. *Peter blutet mit der Wunde.
Peter bleeds with the wound

There is also a set of verbs of sound emission which rejects that kind of alternation, namely those which take an agentive emitter as single argument. Examples include the verbs of sound produced by animals as well as such verbs as German brüllen 'roar, howl' or schreien 'yell.' The examples in (9) illustrate this point for the German verb bellen 'bark,' which takes an agentive emitter. That the requirement of an agentive emitter blocks the alternation shows that it is restricted to verbs for which the emitter does not have control over the situation. ${ }^{2}$

\footnotetext{
$1 \quad$ Foley \& Van Valin (1984) introduce the notion 'effector' as a cover term for dynamic event participants and subsumes the thematic roles 'agent,' 'force' and 'instrument' under this label (see also Van Valin \& Wilkins 1996 on this point).

2 Sentence (9c) is not ungrammatical but only allows for a comitative interpretation of mit dem Hund expressing that Peter barked togehther with the dog.
} 
(9)
a. Der Hund bellt.
the dog barks
'The dog is barking.'
b. *Peter bellt den Hund.
Peter barks the dog
c. \#Peter bellt mit dem Hund.
Peter barks with the dog

A further possible, but also restricted, alternation type is the realization of a cognate object. The cognate object construction allows making the emitted stimulus explicit but it requires a context in which the explication of something, which is already encoded in the verb, is relevant. This can be achieved by a further specification of the emitee as shown in (10).
a. Das Insekt blutet grünes Blut.
the insect bleeds green blood
'The insect is bleeding green blood.' the girl laughs a hoarse laugh 'The girl is laughing a hoarse laugh.'
b. Das Mädchen lacht ein heiseres Lachen.

Verbs of emission vary according to the aktionsart classes they belong to. Rappaport Hovav \& Levin $(2000,283)$ observed that "verbs of emission fall along a continuum of stativity, with verbs of smell emission being the most stative, verbs of light emission slightly less stative, followed by verbs of sound emission and substance emission, which are the most process-like." The wieder/weiter test discussed in chapter 3 reveals that verbs of smell emission and verbs of light emission are stative, whereas verbs of sound emission and verbs of substance emission express activities. Examples (11) to (14) illustrate this test for each subclass separately. 
(11) Der Hund stank letzten Sommer, stank das restliche fahr nicht the dog stunk last summer stunk the remaining year not und stinkt diesen Sommer wieder/ * weiter. and stinks this summer again further 'The dog stunk last summer, didn't stink for the rest of the year but this summer he stinks again.'

(12) Die Lampe leuchtete gestern Abend, war dann aus und the lamp shined yesterday evening was then out and leuchtet jetzt wieder/ weiter.

shines now again further.

'The lamp was shining yesterday evening, it was turned out overnight but now it's shining again.'

(13) Der Hund bellte vor dem Essen, war dann leise und bellt the dog barked before the meal was than silent but barks jetzt wieder/ weiter. now again further 'The dog barked before the meal, then it was silent and now it's barking again/it continues to bark.'

(14) Die Wunde blutete gestern, hörte zwischenzeitlich auf $z u$ the wound bleed yesterday stopped meanwhile PART to bluten und blutet jetzt wieder/ weiter. bleed and bleeds now again further 'The wound bled yesterday, meanwhile it stopped bleeding but now it's bleeding again/it continues to bleed.'

The activity status of verbs of sound emission is independent of the animacy of the emitter. This is illustrated by the examples in (13) and (15). The emitter is agentive in (13) but nonagentive in (15).

(15) Der Motor dröhnte, war eine Weile leise und dröhnte dann the engine droned was a while silent and droned then wieder/ weiter. again further 'The engine droned for a while, was silent and then it droned again/continued droning.' 
At least in German, emission verbs do not fall in a continuum of stativity; rather, there is a clear distinction between stative verbs of emission, verbs of smell and light emission, and those that are activity predicates. Beside stative and activity predicates, there are also semelfactive verbs of emission of light and sound emission, such as donnern 'thunder' and blitzen 'light, flash.' The contrast between semelfactive and non-semelfactive emission verbs is shown in (16). The time adverbial stundenlang 'for hours' indicates that there was a single raining event that lasted for hours (16a) but in (b) it is required that it lightninged repeatedly. A single event interpretation meaning a single lightening - is not possible for the sentence.
a. Es hat stundenlang geregnet.
it has hours.long rained
'It rained for hours.'
b. Es hat stundenlang geblitzt.
it has hours.long lightninged
'It lightninged for hours.'

Despite the difference in aktionsart, verbs of emission can uniformly be paraphrased with 'emitter emits stimulus/substance.' The paraphrases for all four subclasses of verbs of emission are listed in (17). The respective stimulus/substance emitted varies from verb to verb.
a. Verbs of smell emission: Emitter emits smell
b. Verbs of light emission: Emitter emits light
c. Verbs of sound emission: Emitter emits sound
d. Verbs of substance emissions: Emitter emits substance

Verbs of smell/sound/light emission differ with regard to the quality of the emitted stimulus. As an example, take the three German verbs of smell emission shown in (18). English paraphrases are shown for each verb, there is one verb describing the emission of an unpleasant smell (stinken), one that denotes the emission of a pleasant smell (duften) and one verb (riechen) which is neutral with regard to this feature. These verbs differ in the quality of the emitted smell but they have in common that they denote the emission of smell. 

a. stinken 'stink'
'emit unpleasant smell'
b. riechen 'smell'
'emit smell'
c. duften 'smell pleasantly'
'emit pleasant smell'

Verbs of substance emission differ with regard to the kind of substance emitted. Bluten 'bleed' denotes the emission of blood, schwitzen 'sweating' describes the emission of sweat and ejakulieren 'ejaculate' the emission of ejaculate. English and German are both quite productive in deriving new verbs of substance emission from nouns denoting substances. Ropertz $(2001,76)$ lists the following verbs, which illustrate the derivation of such verbs from nouns: milchen 'emit milk' derived from the noun Milch 'milk,' mehlen 'emit flour' from Mehl 'flour', sanden 'emit sand' from Sand 'sand.' For other classes of emission verbs, such a derivational process is less productive. Only verbs of sound emission allow a productive derivation from onomatopoetic sound words. But even if many verbs of substance emission are denominal, not all of them are. Goldberg $(2005,22)$ mentions, for example, the English verbs sneeze and blow which do not have nominal counterparts. These examples are of particular importance for her discussion of 'implicit theme arguments.' Goldberg $(2005,20 \mathrm{f}$.) lists the examples in (19) and states that "the theme argument is unexpressed despite the appearance of an overt directional." There is only one overt argument in the sentences but it is not the referent of this argument that moves into some direction, rather it is the referent of the unexpressed theme argument (19f). The unexpressed theme of (19f) is whatever Pat is vomiting.
a. Pat sneezed onto the computer screen.
b. Chris blew into the paper bag.
c. Don't spit into the wind.
d. The hopeful man ejaculated into the petri dish.
e. Sam pissed into the gym bag.
f. Pat vomited into the sink.

Goldberg claims that in many of the examples in (19) the theme is semantically incorporated into the verb, "in the sense that the theme's 
existence and motion is entailed by the verb" (Goldberg, 2005, 21). But she uses the verbs sneeze and blow, which are not derived from nouns, as arguments against a syntactic incorporation (in the sense of Hale \& Keyser 1993) of the theme argument. ${ }^{3}$ Hale \& Keyser assume that a nominal head is syntactically incorporated into a light verb construction to derive denominal verbs such as bleed. However, Goldberg argues that if no corresponding noun exists, such a derivational process is unlikely. I follow her argumentation and assume that all verbs of emission, not only verbs of substance emission, have an implicit argument which is semantically incorporated. The implicit argument is the emittee, i.e., the stimulus or substance emitted in the eventuality and therefore I speak of an implicit emittee argument rather than an implicit theme argument. The paraphrases in (17) make the incorporated semantic argument explicit. In the following, I will take the emitted stimulus/substance as a semantically incorporated and therefore implicit emittee argument. In the remainder, I will not go into a detailed discussion of the lexical differences of the verbs of emission within the different subclasses but see Atkins et al. (1988); Atkins \& Levin (1991); Levin (1991); Levin et al. (1997) for (English) verbs of sound emission and Gerling \& Orthen (1979) for a discussion of (German) verbs of light emission.

\subsection{Degree gradation of verbs of smell emission}

Verbs of smell emission form a rather limited set of verbs, the three most frequent German exponents of this subtype are riechen 'smell,' duften 'smell pleasantly' and stinken 'stink.' Gamerschlag (2014) lists further but very infrequent examples, which I will not include in the current discussion. A semantic representation for these three verbs is shown in (20). Riechen is characterized by four conjuncts; the first specifies the eventuality as being an emission. The emitter is represented as a syntactic argument as it is bound by the lambda operator. The emittee, which is the implicit semantic argument, is decribed by the last two conjuncts. In the first conjunct, the emittee is introduced and the predicate in the second one specifies it as

Note that the notion of an 'implicit argument' is mostly used in a syntactic sense; cf. the discussion of this notion in Bhatt \& Pancheva (2006). 
being smell. Verbs of smell/sound/light emission differ with respect to the quality they attribute to the theme argument. This can be captured by a further predicate like 'pleasant(y)' and 'unpleasant(y)' in (20b) and (c).

$$
\begin{aligned}
& \text { a. } \llbracket \operatorname{riechen} \rrbracket=\lambda \mathrm{x} \lambda \mathrm{v} \exists \mathrm{y}(\operatorname{emit}(\mathrm{v}) \wedge \operatorname{EMITTER}(\mathrm{v})=\mathrm{x} \wedge \\
& \operatorname{EMITTEE}(\mathrm{v})=\mathrm{y} \wedge \operatorname{smell}(\mathrm{y}) \\
& \text { b. } \llbracket \operatorname{duften} \rrbracket=\lambda \mathrm{x} \lambda \mathrm{v} \exists \mathrm{y}(\operatorname{emit}(\mathrm{v}) \wedge \operatorname{EMITTER}(\mathrm{v})=\mathrm{x} \wedge \\
& \operatorname{EMITTEE}(\mathrm{v})=\mathrm{y} \wedge \operatorname{smell}(\mathrm{y}) \wedge \operatorname{pleasant}(\mathrm{y}) \\
& \text { c. } \llbracket \text { stinken } \rrbracket=\lambda \mathrm{x} \lambda \mathrm{v} \exists \mathrm{y}(\operatorname{emit}(\mathrm{v}) \wedge \operatorname{EMITTER}(\mathrm{v})=\mathrm{x} \wedge \\
& \operatorname{EMITTEE}(\mathrm{v})=\mathrm{y} \wedge \operatorname{smell}(\mathrm{y}) \wedge \text { unpleasant }(\mathrm{y})
\end{aligned}
$$

All three verbs of smell emission can be graded by sehr, as the examples in (21) to (23) reveal.

(21) Also dass zwei Farbmäuse [...] sehr stinken, kann ich mir [...] nicht so that two mice very stink can I me not vorstellen.

imagine

'I cannot imagine that two mice stink very much.' $G$

(22) Er hat weißrose Blüten, die sehr duften. he has white.pink blossoms that very smell.pleasantly 'He has white and pink blossoms which smell very pleasant.' $G$

(23) Die Wandfarbe stinkt sehr. the wall.paint stinks very 'The wall paint really stinks.' $G$

Sehr modifies the intensity of the emitted smell, which can be paraphrased as 'emitting a strong smell.' The paraphrases of ungraded (a) and graded verbs of smell emission are shown in (24). 'Intensity' is a property of the implicit emittee argument and provides a further specification of the theme.

$$
\begin{aligned}
& \text { a. Verbs of smell emission: Emitter emits smell } \\
& \text { b. sehr + Verbs of smell emission: Emitter emits intense/strong } \\
& \text { smell }
\end{aligned}
$$

Intensity of a smell is not the same as the quality of a smell. If something stinkt sehr 'stinks very much' the strength of the smell is 'high' but it does 
not mean that the smell is of a worse quality than something else. So sehr stinken does not mean 'smell very unpleasant' rather it means 'smell unpleasant and very intense.' Therefore, I keep the quality specification of the smell and the indication of its intensity apart. A semantic representation of graded verbs of smell emission is shown in (25). The attribute INTENSITY takes the implicit emittee as its argument and returns the degree of its intensity. Sehr further specifies the intensity degree as 'high.' The INTENSITY attribute is retrieved from the conceptual knowledge associated with 'smell.' We know that smell is characterized by different attributes, one of them is Intensity. The degree context requires the activation of this attribute and as no appropriate scale is part of the lexical meaning of the verb, it is retrieved from the conceptual knowledge. The implicit emittee argument gives access to the conceptual knowledge as it is semantically incorporated and therefore part of the verb's lexical meaning.

$$
\begin{aligned}
& \text { a. } \llbracket \text { sehr riechen } \rrbracket=\lambda \mathrm{x} \lambda \mathrm{v} \exists \mathrm{y}(\operatorname{emit}(\mathrm{v}) \wedge \operatorname{EMITTER}(\mathrm{v})=\mathrm{x} \wedge \\
& \operatorname{EMitTEE}(\mathrm{v})=\mathrm{y} \wedge \operatorname{smell}(\mathrm{y}) \wedge \operatorname{high}(\operatorname{InTENSity}(\mathrm{y})) \\
& \text { b. } \quad \text { sehr duften } \rrbracket=\lambda \mathrm{x} \lambda \mathrm{v} \exists \mathrm{y}(\operatorname{emit}(\mathrm{v}) \wedge \operatorname{EMITTER}(\mathrm{v})=\mathrm{x} \wedge \\
& \operatorname{EMitTeE}(\mathrm{v})=\mathrm{y} \wedge \operatorname{smell}(\mathrm{y}) \wedge \operatorname{pleasant}(\mathrm{y}) \wedge \operatorname{high}(\operatorname{Intensity}(\mathrm{y})) \\
& \text { c. } \llbracket \text { sehr stinken } \rrbracket=\lambda \mathrm{x} \lambda \mathrm{v} \exists \mathrm{y}(\operatorname{emit}(\mathrm{v}) \wedge \operatorname{EMITTER}(\mathrm{v})=\mathrm{x} \wedge \\
& \operatorname{EMITTEE}(\mathrm{v})=\mathrm{y} \wedge \operatorname{smell}(\mathrm{y}) \wedge \text { unpleasant }(\mathrm{y}) \wedge \\
& \operatorname{high}(\operatorname{InTENSIty}(\mathrm{y}))
\end{aligned}
$$

The INTENSITY attribute is linked to the eventuality via an attribute chain which can be represented as in (26). INTENSITY is an attribute of the implicit emittee argument, which again is an attribute of the eventuality. I use representations like in (26) to illustrate the relevant attributes that link the attribute representing the gradable property to the eventuality.

$$
\lambda \mathrm{v}(\operatorname{high}(\operatorname{InTensity}(\operatorname{Emittee}(\mathrm{v}))))
$$

Like German, French and Russian also admit degree gradation of verbs of smell emission. This is shown in (27) for French and in (28) for Russian. As in German, the intensifier specifies the intensity of the emitted smell.

$$
\begin{aligned}
& \text { Le chien pu beaucoup. } \\
& \text { the dog stinks a lot } \\
& \text { 'The dog stinks very much.' }
\end{aligned}
$$




$$
\begin{aligned}
& {[. . .] \text { na stol-e stojala malen'kaja žestjanaja lampočka s }} \\
& \text { PREP table-LOc stood small tin lamp.NOM with } \\
& \text { kerosin-om kotoryj očen' vonjal. } \\
& \text { kerosine-INST which very stank } \\
& \text { 'On the table stood a small tin lamp with kerosene, which stank } \\
& \text { very much.' }
\end{aligned}
$$

Grammatical aspect does not have any effect on the gradation of verbs of smell emission. Since verbs of smell emission are stative, they require a shift to a non-stative interpretation if they are used in the perfective aspect. This is illustrated for Polish in (29). The verb śmierdzieć 'stink' is imperfective and denotes the state of stinking. Adding the prefix $z a$ - derives a perfective verb that means 'begin to stink.' The state denoted by the case verb is the result state of the change introduced by the prefix $z a$-. Bardzo indicates in (a) the intensity of the smell, whereas in (b) it specifies the degree of change. The sentence in (b) expresses a change in the intensity of smelling, from some unspecified intensity to a high degree. This is similar to the effect of verb gradation in the case of degree achievements.
a. Jan bardzo śmierdziat. Jan very stank 'Jan stank very much.'
b. Jan bardzo za-śmierdziat. Jan very ZA-stank 'Jan began to stink very much.'

The German verb riechen 'smell' can also be used in a perception verb sense. In this case, it is used transitively and an experiencer argument is added in subject position (30). Neither duften nor stinken can be used in such a construction. Constructions like the one in (30) are called 'subject-oriented' Whitt (2009). They are transitive and the experiencer is realized as the subject, whereas the stimulus is in object position.

$$
\begin{aligned}
& \text { Ich habe Gas gerochen. } \\
& \text { I have gas smelled } \\
& \text { 'I smell gas.' }
\end{aligned}
$$


Degree gradation is also possible in such a construction (31).

(31) Ich habe das Gas sehr gerochen.

I have the gas very smelled

'I could really smell gas.'

Riechen not only licenses a subject-oriented perception verb use but also an object-oriented one (Viberg 1984, 2001 calls it 'phenomenon based'). Whitt (2009) describes such object-oriented perception verb uses as intransitive constructions in which the experiencer argument is optional, if it is possible at all. The meaning of such constructions is as follows: "the object-oriented perception verbs tend to indicate an assessment or value judgment made by the speaker that is based on perception" (Whitt, 2009, 1085). A German example is shown in (32).

Die Jacke riecht nach Pferd.

the jacket smells of horse

'The jacket smells of horse.'

Gamerschlag \& Petersen $(2012,6)$ list the valency patterns in (33) as the major construction types of object-oriented perception verbs. The adjective in (a) specifies the type of smell of the subject referent. Sü $\beta$ 'sweet' can be taken as a direct specification of the type of smell. Petersen \& Gamerschlag (2014), following Gisborne (2010), call this an attributive use of perceptions verbs. This use contrasts with more indirect constructions such as The apples smell ripe. Ripe does not indicate a kind of smell rather ripe is a state of the apples which can be inferred by the smell of the apples (for a discussion of such inferential uses of perception verbs cf. Gamerschlag \& Petersen 2012). In (b) to (d) the type of smell is indicated by some reference object, which is introduced by a PP in (b) and (c) and by a complement clause in (d).
a. Die Äpfel riechen süß. the apples smell sweet 'The apples smell sweet.'
b. Die Äpfel riechen wie Bananen. the apples smell like bananas 'The apples smell like bananas.' 
c. Die Äpfel riechen nach Bananen. the apples smell of bananas 'The apples smell of bananas.'

d. Die Äpfel riechen als ob sie Bananen wären. the apples smell as if they bananas would.be 'The apples smell as if they were bananas.'

All these constructions license the degree intensifier sehr, only (d) needs some refinement by adding the particle so 'so, as, like.' (34a) is not an instance of verbal degree gradation; rather the intensifier modifies the adjective süß 'sweet.' If there is an adjective present, it is not possible to relate sehr to an intensification of the verb. In all the other examples in (34) sehr intensifies the verb. But the interpretation of degree gradation in these examples differs from the one of plain verbs of smell emission. In (34b) to (d) it is not the intensity of the emitted smell that is specified, but the similarity relation induced by the object of comparison.
a. Die Äpfel riechen sehr süß.
the apples smell very sweet
'The apples smell very sweet.'
b. Die Äpfel riechen sehr wie Bananen.
the apples smell very like bananas
'The apples smell very much like bananas.'
c. Die Äpfel riechen sehr nach Bananen.
the apples smell very of bananas
'The apples smell very much of bananas.'
d. Die Äpfel riechen sehr so als ob sie Bananen wären. the apples smell very so as if they bananas would.be 'The apples smell very much as if they were bananas.'

What a sentence like (34c), for example, means is that the apples smell similar to bananas, or put differently, the smell of the apples is similar to the smell of bananas. Sehr indicates that the smell is not only similar but similar to a high degree. The construction introduces a new gradable property, namely 'similarity' between two objects and the intensifier applies to it.

This effect is not limited to the object-oriented perception verb uses of verbs of smell emission but also shows up with strong resultative constructions, which is exemplified by the verb of sound emission schreien 'shout' 
in (35). In (a), the verb is intensified by sehr, which specifies the loudness of the shouting. ${ }^{4}$ A resultative construction is shown in (b) and in (c) the intensifier sehr and the resultative construction are combined. Sehr can only modify the resultant state - the boy shouts himself very hoarse - but not the loudness of the emitted sound. In English, it is obvious that in (35c) the resultative predicate rather than the verb is intensified. This is indicated by the use of very, which is restricted to adjectives and not possible with verbs.
a. Der funge schreit sehr. the boy shouts very 'The boy shouts a lot.'
b. Der funge schreit sich heiser. the boy shouts REFL hoarse 'The boy shouts himself hoarse.'
c. Der funge schreit sich sehr heiser. the boy shouts REFL very hoarse 'The boy shouts himself very hoarse.'

If the resultative predicate is not gradable, sehr cannot be added to the sentence (36). This indicates that in resultative constructions only the resulting state can be graded, but the scale contributed by the verb is no longer admissible for degree modification.
a. Der funge schreit sich in den Schlaf. the boy shouts REFL in the sleep 'The boy shouts himself to sleep.'
b. ${ }^{*}$ Der funge schreit sich sehr in den Schlaf. the boy shouts REFL very in the sleep

The fact that degree gradation applies to the similarity scale in the case of object-oriented perception verb uses of riechen and to the scale introduced by the resultative predicate depends on the fact that in these cases the scale is introduced by the morphosyntactic construction. Since the scale is overtly encoded, it is not required to retrieve a scale from the conceptual knowledge. If the scale is not suitable for sehr, as in (36b), degree gradation is not possible. This shows that overtly encoded scales block the retrieve-

\footnotetext{
$4 \quad$ Degree gradation of verbs of sound emission is discussed in more detail in section 7.4.
} 
ment of scales from conceptual knowledge and the activation of scales from conceptual knowledge seems to be a last resort strategy if neither the lexical semantics of the verb nor the morphosyntactic construction encodes a scale.

\subsection{Degree gradation of verbs of light emission}

Verbs of light emission are, like verbs of smell emission, stative predicates, but they are more numerous than verbs of smell emission. Gerling \& Orthen (1979) provide a classification of German verbs of light emission that is based on features like 'continuous' vs. 'non-continuous light emission' or 'direct' vs. 'indirect emission.' Indirect light emission would cover light reflection phenomena, whereas direct light emission covers the production of light. A continuous light emission is denoted by such verbs as leuchten, scheinen 'shine,' whereas flackern, flimmern 'flicker' denotes a non-continuous one. I am not going into the details of Gerling \& Orthen's work since it is not my aim to provide a lexicographic analysis of these verbs. But the feature 'continuous' vs. 'non-continuous' light emission indicates that this type of emission is less stative than smell emission. Hence, some verbs of light emission are more dynamic than others.

Verbs of light emission license degree gradation similarly to verbs of smell emission. Examples of graded verbs of light emission are shown in (37) and in each case, sehr modifies the intensity of the emitted light. INTENSITY, in the case of light emission, means the degree of brightness. (37c), for example, means that the eyes do not only sparkle but sparkle intensively and therefore brightly.

a. Von Geburt an habe ich sehr helle Augen, die sehr of birth on have I very bright eyes which very leuchten in der Sonne. shine in the sun 'Since birth I have had very bright eyes, which shine very much in the sun.' $G$

b. Diamanten glänzen in der Sonne sehr. diamonds gleam in the sun very 'Diamonds gleam very much in the sun.' $G$ 
c. Da die Steinchen sehr funkeln, ist diese Kette ein echter since the stones very sparkle is this necklace a real Eye Catcher.

eye-catcher

'The necklace is a real eye-catcher because the stones sparkle very much. ${ }^{\prime}$

The verbs in (37) all express an indirect emission of light but we get the same effect with more direct cases of light emission, as those in (38). The emitted light is characterized as intensively and therefore brightly.
a. Die Lampe leuchtet sehr. the lamp lights very 'The lamp is very bright.'
b. Die Sonne scheint sehr. the sun shines very 'The sun is shining a lot [intensively].'

We find the same interpretation in Russian as shown with the perfective verb iskrit'sja 'sparkle' in (39). Očen' specifies the intensity of the emitted light.

$$
\begin{aligned}
& \text { Kogda letel sneg on očen' iskril-sja na svet-u. } \\
& \text { when flew snow.NOM he very sparkled-REFL PREP light-LOC } \\
& \text { 'When the snow was falling, it sparkled very much in the light.' }
\end{aligned}
$$

The meaning of the examples discussed so far can be partially paraphrased as indicated in (40). The paraphrase is the same as the one for verbs of smell emission; the only difference is that intensity is differently interpreted in the context of light and smell.

$$
\begin{aligned}
& \text { a. Verbs of light emission: Emitter emits light } \\
& \text { b. sehr + Verbs of light emission: Emitter emits intense light }
\end{aligned}
$$

As the paraphrases for degree gradation of verbs of light emission, and verbs of smell emission do not differ, the semantic representation of these cases is also the same. I assume that verbs of light emission allow retrieving an intensity scale from the conceptual knowledge associated with the implicit emittee argument. (41) shows the semantic representation of the 
graded verb funkeln 'sparkle.' The relevant attributes for verbal degree gradation and how they are linked to the eventuality is shown in (42).

$$
\begin{aligned}
& \llbracket \operatorname{sehr} \text { funkeln } \rrbracket=\lambda \mathrm{x} \lambda \mathrm{v} \exists \mathrm{y}(\operatorname{emit}(\mathrm{v}) \wedge \operatorname{EMITTER}(\mathrm{v})=\mathrm{x} \wedge \\
& \operatorname{EMITTEE}(\mathrm{v})=\mathrm{y} \wedge \operatorname{light}(\mathrm{y}) \wedge \operatorname{sparkling}(\mathrm{y}) \wedge \operatorname{high}(\operatorname{InTENSity}(\mathrm{y})) \\
& \lambda \mathrm{v}(\operatorname{high}(\operatorname{InTEnsity}(\operatorname{EMITTEE}(\mathrm{v}))))
\end{aligned}
$$

With regard to verbal degree gradation, the distinction between continuous and non-continuous light emission is relevant. Verbs like flackern 'flicker', blinken 'twinkle' and blitzen 'light, flash' are semelfactive predicates which are ambiguous between a single event and an iterative reading. The sentences in (43) seem to license two different interpretations of verbal degree gradation: either the emitted light was very intense or the emission of light happened frequently. This looks as if sehr is ambiguous between degree and extent gradation with such verbs.

a. Ihr Paillettenkleid blinkt im Discolicht sehr. her pailette.dress twinkles in.the disco.light very 'Her sequined dress twinkles very much in the disco light.' $G$

b. [...] man hat mir heute morgen gesagt, dass es sehr one had me today morning said that it very geblitzt und gedonnert hat. lightninged and thundered had '[...] someone told me this morningthat there was a lot of thunder and lightning., $G$

We observe the same ambiguity in Russian, as shown by the example in (44). According to my informants, the default interpretation is that the LCD monitor flickered very intensly, meaning brightly. But there is also an interpretation that it flickered very often.

$$
\begin{aligned}
& \text { Popal-sja kak-to brakovannyj LCD monitor, očen' migal } \\
& \text { got-REFL once defective LCD-monitor.NOM very blinked } \\
& \text { podsvetk-oi na nekotor-yx urovn-jax jarkost-i. } \\
& \text { backlight-INST PREP some-LOC level-LOC brightness-GEN } \\
& \text { 'Got a defective LCD monitor once, its backlight flickered a lot on } \\
& \text { some brightness levels.' }
\end{aligned}
$$


I will discuss degree gradation of semelfactive verbs of emission in more details in the next section, after presenting the relevant data on semelfactive verbs of sound emission.

\subsection{Degree gradation of verbs of sound emission}

Verbs of sound emission are activity predicates. The respective sound can be either produced by an agentive (bark) or a non-agentive emitter (drone). Agentivity of the emitter does not affect degree gradation of these verbs, as shown in (45) . Dröhnen 'drone' is a verb that takes non-agentive emitter, lärmen 'make noise' does not necessarily require an agentive emitter but the sentence in (b) can be understood in the sense that the guests voluntarily did something (e.g. talking) and thereby produced noise. In (c), the emitter - Kreide 'chalk' - is not agentive but there is an effector present in the sentence which is responsible for the chalk emitting some squeaking sound. Das Kind 'the child' is an active emitter in (d), who is responsible for emitting the scream. Degree gradation has the same effect in all four cases, namely to specify the intensity of the emitted sound. In (b), for example, the guests not only produce noise but the noise they produce is very intense. In the context of sound emission, intensity means 'loudness' or 'volume.' I will use the term 'loudness' to refer to 'sound intensity' in the remainder of the thesis.

(45) a. Der Bass hat immer sehr gedröhnt und klang unpräzise the bass has always very droned and sounded imprecise und weich.

and soft

'The bass always droned a lot and sounded imprecise and soft. ${ }^{\prime} G$

b. In der letzten Nacht haben Gäste bis morgens um 2:00 in the last night have guests till morning at 2:00 Uhr sehr gelärmt [...]. o'clock very made noise

'Last night, guests made a lot of noise till 2 o'clock in the morning $[\ldots]]^{, G}$ 
c. Beim Schreiben an der Tafel hat er sehr mit der at.the writing on the blackboard has he very with the Kreide gequietscht.

chalk squeaked

'While writing on the blackboard, he squeaked a lot with the chalk. ${ }^{G}$

d. Das Kind hat sehr geschrien.

the child has very screamed

'The child screamed a lot. ${ }^{\prime}$

As was the case for the other two subclasses of verbs of emission, degree gradation applies to an intensity scale which measures a gradable property of the implicit emittee argument. Degree gradation of verbs of sound emission can be paraphrased as in (46). Since we have the same pattern as for the other subclasses of emission verbs, the semantic representation of graded verbs is also the same (47). As agentivity does not affect degree gradation, it is ignored in the semantic representations. The attributes relevant for degree gradation is this case as shown in (48).

(46) a. Verbs of sound emission: Emitter emits sound

b. sehr + Verbs of sound emission: Emitter emits intense sound

$$
\begin{aligned}
& \llbracket \operatorname{sehr} \operatorname{schreien} \rrbracket=\lambda \mathrm{x} \lambda \mathrm{v} \exists \mathrm{y}(\operatorname{emit}(\mathrm{v}) \wedge \operatorname{EMITTER}(\mathrm{v})=\mathrm{x} \wedge \\
& \operatorname{EMITTEE}(\mathrm{v})=\mathrm{y} \wedge \operatorname{shout}(\mathrm{y}) \wedge \operatorname{high}(\operatorname{InTENSity}(\mathrm{y})) \\
& \lambda \mathrm{v}(\operatorname{high}(\operatorname{InTENSity}(\operatorname{EMITTEE}(\mathrm{v}))))
\end{aligned}
$$

In the last section, it was mentioned that semelfactive verbs of light emission license a frequentative interpretation of verbal degree gradation. The same effect shows up with semelfactive verbs of sound emission, such as schreien 'scream' in (45d) or bellen 'bark' in (49a). Sehr either modifies the intensity of the emitted sound or the frequency of the emission of barking sounds. The intensity reading can be forced by a strictly semelfactive context like in (49b) in which a single emission is expressed. Einmal 'once' restricts the verb to a single event reading and in such a context sehr can only modify the intensity of the sound but not the frequency of its emission. 

a. Ihr Hund bellt aber sehr! your dog barks but very 'Your dog barks a lot!'
b. Ihr Hund hat einmal sehr gebellt. your dog has once very barked 'Your dog barked once very loudly.'

As already mentioned with regard to semelfactive verbs of light emission, the same ambiguity in interpretation of degree gradation shows up in Russian. In (50), either the subject referent coughed loudly or often. The verb kašljat' 'cough' is imperfective and has an iterative interpretation; a semelfactive verb can be derived by adding the suffix $-n u$ which yields the perfective verb kašljanut' 'cough once.' Grading the explicitly marked semelfactive verb does not give rise for a frequentative interpretation.

$$
\begin{aligned}
& U \text { menja byl bronxit, ja pozvonila doktoru Simony } i \\
& \text { by me was bronchitis I called doctor Simon and } \\
& \text { skazala, čto ja očen' kašlaju. } \\
& \text { said that I very cough } \\
& \text { 'I had bronchitis; I called Dr. Simon and told him that I cough a } \\
& \text { lot.'R }
\end{aligned}
$$

The question is whether examples such as those in (49) and (50) reveal that there is no strict separation between degree and extent gradation and that intensifiers such as sehr and očen' can be used for degree as well as extent gradation. I like to argue that this is not the case. A frequentative interpretation is an implicature but not the primary semantic effect of verbal degree gradation. This is shown by the German examples in (51) and the Russian ones in (52). The German examples show that sehr bellen 'bark very much' really means bark loudly and not barking for a long time. It is the degree and not the extent that is modified by sehr since it is possible to say that a dog barked very much but only shortly. At the same time, it cannot be negated that the dog barked loudly. Since the indication of a high frequency or long duration can be canceled, it is merely an implicature. The same is true for Russian since očen' kašljat' 'cough very much' does

The sentence is ambiguous and either means 'The dog emitted a single bark' or 'At a single occasion, the dog barked'. I focus on the first reading. 
not entail mnogo kašljat' 'cough a lot' which can be negated without contradiction. But a contradiction arises if one states that the subject referent coughed very much but not loudly (52b).

a. ??Gestern hat der Hund wieder sehr gebellt, aber nur yesterday has the dog again very barked but only leisel nicht laut. silently not loud 'The dog barked a lot again yesterday, but not loudly.'

b. Gestern hat der Hund wieder sehr gebellt, aber nicht yesterday has the dog again very barked but not lange/ nur kurz.

long only short

'The dog barked a lot again yesterday, but not for long.'

a. On očen', no ne mnogo, kašljal.

he very but not much coughed

'He coughed loudly [= very], but not for long [= much].'

b. \#On očen', no ne gromko, kašljal.

he very but not loudly coughed

'He coughed a lot, but not very loudly.'

Why does the apparent ambiguity of the degree intensifier show up with verbs such as bellen 'bark' and kašljat' 'cough' but not with verbs such as dröhnen 'drone' or wachsen 'grow'? Bellen and kašljat' are compatible with the expression of an iteration of single sound emissions. Hence, they lexically license a frequentative reading since a scale measuring the frequency of the eventuality is grounded in the verb's meaning. A semantic representation for sehr bellen is given in (53), where we have an attribute FREQUENCY, which is a gradable property of the eventuality and measures the number of event occurences. This property has a minimal standard entailing that the frequency is greater than or equal to one. Russian has a grammaticalized device for restricting the the frequency to one - which is a single event - , by using the semelfactive affix $-n u$.

$$
\begin{aligned}
& \llbracket \operatorname{sehr} \text { bellen } \rrbracket=\lambda \mathrm{x} \lambda \mathrm{v} \exists \mathrm{y}(\operatorname{emit}(\mathrm{v}) \wedge \operatorname{EMITTER}(\mathrm{v})=\mathrm{x} \wedge \operatorname{\operatorname {mitTteE}}(\mathrm{v})=\mathrm{y} \\
& \wedge \operatorname{bark}(\mathrm{y}) \wedge \operatorname{high}(\operatorname{InTENSITt}(\mathrm{y}) \wedge \operatorname{FrEQUENCY}(\mathrm{v}) \geq 1)
\end{aligned}
$$


For semelfactive verbs, I assume that FREQUENCY is a lexically encoded gradable property and therefore accessible for degree intensifiers, which operate on the level of the predicate. Verbs such as dröhnen or wachsen do not lexically encode a frequency scale and hence do not give rise to a frequency reading of sehr, resp. očen'. The picture looks different if we combine verbs of non-continuous sound emission with adverbial expressions of extent gradation like German viel (54). In this case, it is only the frequency or temporal duration which is modified but not the intensity of the emitted sound.

$$
\begin{aligned}
& \text { Der Hund hat viel gebellt. } \\
& \text { the dog has much barked } \\
& \text { 'The dog barked a lot.' }
\end{aligned}
$$

To conclude this discussion: degree gradation leads to an extent implicature with semelfactive verbs of light and sound emission. This is based on the fact that the verbs lexically encode a scale measuring the frequency of the eventuality.

Atkins et al. (1988); Atkins \& Levin (1991); Levin (1991) and Levin et al. (1997) discuss further uses of verbs of sound emission which are illustrated for German in (55). In these cases, the emitter is not only producing a sound but does so with a communicative intention. In (a) and (b) the respective sound is emitted to warn someone. The difference then is that the intended receiver is explicitly realized in (b) but not in (a). In (c), what is emitted, i.e., the content of the communication, by the communicator is specified by the subordinate clause.
a. Er pfeift eine Warnung.
he whistles a warning
'He whistles a warning.'
b. Er schreit ihm eine Warnung $z u$.
he shoutes him a warning PART
'He is shouting a warning to him.'
c. Er grunzte, dass er gehen will.
he grunted that he go wants
'He grunted that he wanted to go.'

These constructions do not license degree gradation by sehr as shown in (56). The verbs are not used as simple verbs of sound emission but rather 
as communication verbs and the INTENSITY attribute cannot be activated in this kind of construction. Probably InTENSITy is not an attribute of a communicated message. To consolidate this claim a deeper investigation of degree gradation of communication verbs would be necessary, but this goes beyond the limits of this thesis.
a. \#Er pfeift sehr eine Warnung. he whistles very a warning
b. \#Er schreit ihm eine Warnung sehr zu. he shouts him a warning very PART
c. \#Er grunzte sehr, dass er gehen würde. he grunted very that he go would

Verbs of sound emission are not stative, and hence they show an aspectual opposition. This is demonstrated for German in (57). We have a contrast between a perfect (57a) and a progressive construction (b) but there is no contrast with regard to degree gradation. In both cases, sehr specifies the intensity of the emitted sound.
a. Der Motor hat sehr gedröhnt.
the engine has very droned
'The engine droned very much.'
b. Der Motor ist sehr am Dröhnen.
the engine is very at.the droning
'The engine is droning very much.'

Again the same is true for Russian, as the examples in (58) show. In (a) we have the imperfective verb lajat' 'bark' and gradation affects the intensity of the emitted sound (leaving aside the extent implicature discussed above). The verb can be combined with various prefixes, not all of them licensing degree gradation. Adding the prefix $n a$-derives a perfective verb with the meaning bark at someone; the prefix transitivizes the verb. In (a) and (b) it is both expressed that the dog barked at a girl. The interpretation of the perfective sentence, with regard to degree gradation, does not differ from the imperfective one. Hence, grammatical aspect does not affect degree gradation of verbs of sound emission. 

a. Sobaka očen' lajala na devočk-u. dog.NOM very barked PREP girl-ACC
'The dog is barking very loudly at the girl.'
b. Sokaba očen' na-lajala na devočk-u. dog.NOM very NA-barked PREP girl-ACC 'The dog barked very loudly at the girl.'

\subsection{Degree gradation of verbs of substance emission}

Verbs of substance emission are activity predicates. Their single argument, as for the other subtypes of emission verbs, is an emitter. But some variance with regard to the emitter argument can be observed. Taking bluten 'bleed' as an example, the emitter can either be a wound (59a), a person (b) or a body part (c). In (b) it is understood that the person is bleeding somewhere on his body, whereas in (a) and (c) it is understood that the wound or the body part belongs to a person or animal.
a. Die Wunde blutet.
the wound bleeds
'The wound is bleeding.'
b. Der Mann blutet.
the man bleeds
'The man is bleeding.'
c. Die Hand blutet.
the hand bleeds
'The hand is bleeding.'

Other verbs of substance emission show less variation regarding the emitter argument. As (60) shows, the verb eitern 'fester' restricts the emitter to being either a wound or a body part but does not license a person as emitter. This is an interesting lexicographic contrast within the class of verbs of substance emission but will be ignored in the remainder of the analysis.
a. Die Wunde eitert.
the wound festers
'The wound is festering.' 
b. \#Der Mann eitert. the man festers

c. Die Hand eitert. the hand festers 'The hand is festering.'

Verbs that express an emission from a body also allow the so-called 'BodyPart Possessor Ascension Alternation' (Levin, 1993, 71) shown in (61). A body part and its possessor can either be realized in a single complex NP, as in (a), or the possessed body part can be expressed in a prepositional phrase (b). As (62) shows, this alternation is not restricted to body parts; nouns like wound can also be licensed as possessum.
a. Seine Hand blutet.
his hand bleeds
'His hand is bleeding.'
b. Er blutet an der Hand.
he bleeds on the hand
'His hand is bleeding.' (lit. 'He is bleeding at his hand.')

(62) a. Seine/Die Wunde blutet.

his/the wound bleeds

'His/the wound is bleeding.'

b. Er blutet aus der Wunde.

he bleeds out the wound

'His wound is bleeding.' (lit. 'He is bleeding from his hand.')

As already mentioned for verbs like donnern 'thunder' and blitzen 'lightning, flash,' weather verbs do not have an emitter argument (63). Syntactically, they are atransitive Van Valin \& LaPolla (1997). The atransitivity of these verbs is more obvious in languages such as Latin (64) where no expletive subject is required. Rather the verb can be used without any explicit argument. This is not simply a case of pro-drop since it can be observed with other intransitive verbs, as it is not possible to have an explicit argument. The same holds for Russian, as will be demonstrated later.

$$
\text { Es regnet. }
$$

it rains

'It is raining.' 
(64) Latin (Romance < Indo-European; Eriksen et al. 2010, 566)

Pluit.

rain.3sG

'It is raining.'

Eriksen et al. $(2010,567)$ state that "[m]eteorological events do not include distinct and salient participants" like agents or patient. This is why we observe the difference in the argument realization of bleed and rain in (59) and (63). It is cross-inguistically attested that meteorological events are denoted by complex predicates, as illustrated by the Basque example in (65). The complex predicate consists of a light verb and a nominal head which denotes the emitted substance.

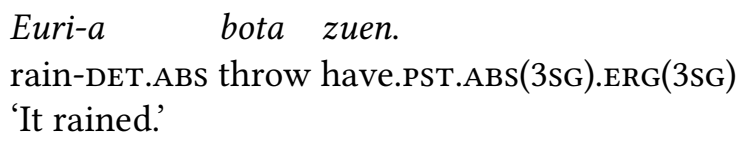

Russian also makes use of such complex construction for the expression of meteorological events. Examples are idti sneg 'snow' (literally 'go snow') or idti grad 'hail' (lit. 'go hail'). Russian also uses such complex predicates for the expression of substance emission. An example is idti krov' 'bleed' (lit. 'go blood'). This is one similarity between weather verbs and verbs of substance emission; a further similarity is that they behave the same with regard to degree gradation. This is the reason why they are put together in this section.

Intransitive verbs of substance emission share some similarities to verbs of sound emission. First, the emitters of some verbs, for example spucken 'spit,' may get an agentive interpretation. But in contrast to verbs like bellen 'bark' the emitter of spucken is not necessarily agentive. The verb can denote an involuntary and therefore uncontrolled process of emission. Second, there is also a distinction between continuous and noncontinuous substance emission. Bluten describes a continuous emission of substance, which can be interrupted, but is potentially temporally unbounded. Spucken refers to the emission of spit, which is not a continuous process. The addition of a durative adverbial indicates a repetition of single emission events (66). 
(66) Der Mann spuckte zehn Minuten lang auf den Boden. the man spat ten minutes long on the floor 'The man spat on the floor for ten minutes.'

Verbs of substance emission, which denote a continuous process of emission, can be graded by sehr. Examples are shown in (67). In each of the cases, sehr specifies the quantity of the emitted substance, which was already described by Ropertz (2001).

(67) a. Da die Wunde sehr geblutet hat, sind meine Eltern mit as the wound very bled has are my parents with mir ins Krankenhaus gefahren. me in.the hospital driven 'As the was wound bleeding a lot, my parents took me to the hospital. ${ }^{G}$

b. Heute Nacht hat es sehr geregnet, [...]. today night has it very rained 'Last night, it rained a lot [...].',

c. Ihre Haare fetten schon nach zwei Tagen sehr. her hairs grease already after two days very 'After two days her hair was already very greasy.' $G$

The sentences in (67) can be paraphrased as indicated in (68). As the paraphrase shows degree gradation affects the quantity of the emitted substance. The degree expression is paraphrased by the adnominal quantity expression viel 'much.'

(68) a. Verbs of substance emission: Emitter emits substance

b. $\quad s e h r+$ Verbs of substance emission: Emitter emits much substance

The semantic representation of graded bluten is shown in (69).

$$
\begin{aligned}
& \llbracket \operatorname{sehr} \text { bluten } \rrbracket=\lambda \mathrm{x} \lambda \mathrm{v} \exists \mathrm{y}(\operatorname{emit}(\mathrm{v}) \wedge \operatorname{EMITTER}(\mathrm{v})=\mathrm{x} \wedge \operatorname{\operatorname {EMITTEE}}(\mathrm{v})=\mathrm{y} \\
& \wedge \operatorname{blood}(\mathrm{y}) \wedge \operatorname{high}(\operatorname{QUANTITY}(\mathrm{y}))
\end{aligned}
$$

The attribute chain that relates the gradation scale to the eventuality is shown in (70). QUANTITY is an attribute of the implicit emittee argument and retrieved from the conceptual knowledge associated with the referent 
of the implicit emittee argument. In (70), we see a difference to the relevant attribute chains in verbs of smell/sound/light emission as we have the attribute QUANTITY instead of INTENSITY. Substances are not characterized by an INTENSITY attribute therefore INTENSITY is not a part of our conceptual knowledge of substances. The only admissible gradable property that can be retrieved from the conceptual knowledge associated with verbs of substance emission is the QUANTITY attribute (for a more detailed discussion see Fleischhauer 2015).

$$
\lambda e(h i g h(\text { euantity(Emittee(e)))) }
$$

Russian provides further evidence for the correctness of the paraphrase. In Russian there are two verbs for bleed. There is a simplex imperfective verb krovotočit' (71) and a complex verb construction idti krov' (72) based on the motion verb idti 'go.' The imperfective simplex verb cannot be perfectivized, but graded by očen'. The interpretation is that the wound is emitting a lot of blood.

$$
\begin{aligned}
& \text { Rana krovotočit očen'. } \\
& \text { wound.NOM bleeds very } \\
& \text { 'The wound is bleeding a lot.' } \\
& U \text { nego idët krov'. } \\
& \text { by him goes blood.NOM } \\
& \text { 'He is bleeding.' }
\end{aligned}
$$

The verb krovotočit' does not license the possessor of the wound as subject argument. To realize the possessor as subject argument, the complex verb construction has to be used (72). In this construction, only the adnominal quantity expression mnogo 'much' can be used but not the degree intensifier očen' (73). Mnogo is used adverbially preceding the verb idti but semantically it modifies the nominal head of the complex verb construction.

$$
\begin{aligned}
& U \text { nego mnogo idët krov'. } \\
& \text { by him much goes blood.NOM } \\
& \text { 'He is bleeding a lot.' }
\end{aligned}
$$

Polish has a similar construction but overtly indicates that the quantity expression duzo 'much' modifies the nominal head of the complex verb 
construction (74a) and (b). As is typical for Slavic languages, the combination of a noun with a quantity expression requires gentive case marking on the noun. Hence, deszcz 'rain' is in the genitive case in (74b). The interpretation, like in the Russian example, is that a lot of rain has fallen.

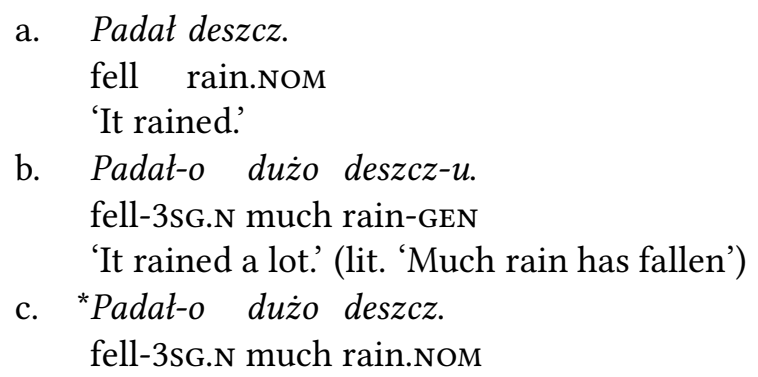

Neither dużo in (74b) nor mnogo in (73) can be interpreted as extent intensifiers. That $d u \dot{z} o$ only functions as a modifier of the nominal head and not of the event predicate (padać deszcz) can be seen by the contrast between (74b) and (c). A combination of $d u \dot{z} o$ and nominal head in nominative case is ungrammatical; deszcz has to be in the genitive if $d u \dot{z} o$ is present.

In contrast to Russian, the Polish complex verb construction can be used in the perfective aspect (75). The interpretation of (75) is similar to (74b), in both cases the quantity of emitted rain is indicated as 'large.'

$$
\begin{aligned}
& \text { Spadło duzo deszcz-u. } \\
& \text { fell much rain-gen } \\
& \text { 'A lot of rain has fallen.' }
\end{aligned}
$$

Grammatical aspect interacts with the degree gradation of verbs of substance emission. With perfective verbs the overall quantity of emitted substance is specified, whereas with progressive verbs it is the rate of emission which is specified (The term 'rate of emission' goes back to Ropertz' (2001) analysis of degree gradation of verbs of substance emission.). This is illustrated in (76) for the German verb bluten 'bleed.' In the perfective reading of the perfect construction (a), sehr indicates that the overall quantity of emitted blood is 'large.' This is different for (b), since the progressive describes an ongoing event. Therefore, it is not possible to indicate the total quantity of emitted blood. Rather the quantity of emitted blood at a certain stage of the event is specified. 

a. Die Wunde hat sehr geblutet.
the wound has very bled
'The wound bled a lot.'
b. Die Wunde war sehr am Bluten.
the wound was very at.the bleeding
'The wound was bleeding a lot.'

In chapter 4, I already mentioned that both readings of degree gradation, the perfective and the progressive one, are related but do not entail each other. If the overall quantity of emitted blood is large, then it is not necessarily the case that at each stage of the event a large quantity of blood has being emitted. Similarly, if at a certain stage of an event someone emits a large quantity of blood, this does not necessarily sum up to the emission of a large overall quantity. At different stages the emitter could emit only a rather small quantity of blood or the bleeding could end before much blood is emitted. Grammatical aspect has a very similar effect on degree gradation of verbs of substance emission as it has on change of state verbs. It is relevant to question what verbs of substance emission and change of state verbs have in common such that grammatical aspect interacts with degree gradation. I will turn to that question in chapter 9, and turn now to some Russian data. ${ }^{6}$

The Russian verb doždit' 'rain' is imperfective and can be intensified by očen'. Russian imperfective aspect shows a range of possible interpretations, as discussed in chapter 4 . Sentence (77a) therefore is ambiguous between two readings, either the total amount of fallen rain is large, or at some time yesterday it rained hard. The first interpretation is related to the denotative use of the imperfective aspect, the second one to the progressive reading. According to my informants, the first reading - specifying the total quantity of rain - is (without any specific context) preferred. Example (b) only has the interpretation that it rains hard, meaning that a large quantity of rain falls at a certain stage of the event. Due to present tense and probably the time adverbial sejčas 'now' only a progressive reading is possible.

In chapter 4, it was shown that grammatical aspect also interacts with degree gradation of verbs of substance emission in French. The crucial data will not be repeated in this chapter. 

a. Segondja očen' doždil.
yesterday very rained
'Yesterday, it rained a lot.'
b. Sejčas očen' doždit.
now very rains
'It is raining hard.'

The verb doždit' can also be perfectivized by, for example, the prefix $z a$-, which adds an inceptive meaning component. Sentence (78) can be used to describe a situation in which it suddenly started to rain hard or in which it already rained but then increased in intensity. We do not get a total quantity interpretation due to the added meaning component of inceptivity.

$$
\begin{aligned}
& \text { Očen' za-doždilo. } \\
& \text { very ZA-rained } \\
& \text { 'It started to rain a lot.' }
\end{aligned}
$$

As already mentioned in chapter 4, Russian prefixes often add further meaning components to the verb. This surely has an effect on the possible outcome of degree gradation, as demonstrated with (78), and therefore makes it hard to really investigate the influence of grammatical aspect on degree gradation by using Slavic data.

So far, the discussion has shown that degree gradation of verbs of substance emission is the same irrespective whether the emitted substance is semantically incorporated in the verb or overtly realized in a complex verb construction. But as the Russian examples have shown, the device used for degree gradation may differ depending on whether we use a simplex verb - in which case we use očen' in Russian - or a complex verb construction - which requires mnogo.

Persian also provides some interesting data on the degree gradation of complex verb constructions. The distribution of Persian degree expressions, which was already mentioned in chapter 2, is illustrated below with help of the relevant data. As (79) shows, kheyli 'very' is used for verbal degree gradation, whereas ziad 'much' is used for extent gradation. Kheyli is also used with adjectives, irrespective of whether they are in the positive (80a) or comparative form (b). Ziad functions as an adnominal quantity expression, as shown in (81). 
a. Oura kheyli dustdarad.

3sG.ACc very like.3sg

'S/he likes him/her very much.'

b. (Tabestane gozashte) ziad baran barid. summer last much rain rained '(Last summer,) it rained a lot.' (= frequency or duration)

(80) a. Ou kheyli ghadboland ast.

3sG very tall is

'He is very tall.'

b. Pesar kheyli bozorg-tar as dushash ast.

boy very taller-comp than his friend is

'The boy is much taller than his friend.'

(81) a. Ou ketabhaye ziadi darad.

3sg books much has

'S/he has many books.'

b. Dar daryache ab ziad ast.

in.the lake water much is

'There is much water in the lake.'

In complex verb constructions, Persian allows both intensifiers as shown in (82). The construction khoonrizi dashtan 'bleed' (literally 'bleeding have') consists of the noun for blood and a verb meaning have. Both examples, (82a) and (b), allow for the reading that the quantity of emitted blood is 'large.' The example in (b) also provides the interpretation that the emitter bleeds often or for a long time, hence the extent reading is possible. This reading is not available in (a). Persian is different from the Slavic languages discussed above and licenses degree as well as extent gradation.
a. Ou kheyli khoonrizi dasht.
3sG very bleeding has
'S/he bled a lot.' (= degree)
b. Ou ziad khoonrizi dasht.
3sG much bleeding has
'S/he bled a lot.' (= extent)

The question arises as to why complex verb constructions (and it only seems to be in such constructions) license extent intensifiers for degree 
gradation? A possible answer suggested by the examples discussed above is that the nominal head of these complex verb constructions could be the reason. Polish shows morphosyntactic evidence that the intensifier, which also functions as an adnominal quantity expression, modifies the nominal head of the construction: the degree expression is placed between the verb and the nominal head and the nominal head requires genitive case marking. In Russian, the opposite pattern can be observed: mnogo precedes the verb and the nominal head remains in nominative case. Although mnogo is used adverbially, semantically it modifies the nominal head.

In German, we find examples that are similar to the Persian ones in (82). Sehr specifies the quantity of emitted blood, which is the degree interpretation as shown above. But (83b) is ambiguous between the interpretation that he bled often, bled for a long time or emitted a lot of blood. Hence, viel bluten also seems to have a degree interpretation in which the quantity of emitted blood is specified.
a. Er hat sehr geblutet.
he has very bled 'He bled a lot.'
b. Er hat viel geblutet.
he has much bled
'He bled a lot.'

A difference between sehr bluten and viel bluten is that the latter does not allow for a degree interpretation if the verb is used in a progressive construction. As discussed in chapter 4, viel shifts the interpretation of the progressive constructions towards a habitual reading (84b).
a. Er ist sehr am Bluten.
he is very at.the bleeding 'He is bleeding hard.'
b. Er ist viel am Bluten.
he is much at.the bleeding 'He bleeds a lot (frequently).'

An explanation for the fact both German and Persian extent intensifiers induce a degree interpretation can go along the following lines: viel as well as ziad indicate either a long duration or a high frequency of events of 
substance emission. The longer the emission of blood continues, the more blood gets emitted. So one can assume that the indication of a large quantity of emitted blood is secondary to and dependent on the specification of the temporal extent. This would also explain why the degree interpretation vanishes in an explicit progressive construction. If this explanation is accepted, viel and ziad would still remain strict extent intensifiers and a degree reading only arises due to the fact that they specify the extent of the event. Nevertheless, this does not provide an explanation of the Slavic data.

To conclude, irrespective of how an event of substance emission is linguistically realized, the effect of degree gradation is always the same, namely to indicate the quantity of emitted substance. Variance only exists in the choice of the intensifiers for which I could not provide a full explanation.

\subsection{Conclusion}

Verbs of emission are not homogeneous with regard to degree gradation. There is a split between verbs of smell/sound/light emission on the one hand and verbs of substance emission on the other hand. The first three subclasses mentioned are graded with respect to the intensity of the implicit emittee argument and degree gradation does not interact with grammatical aspect. The last mentioned class is graded with regard to the quantity of the implicit emitee argument and degree gradation interacts with grammatical aspect. The question, "what makes verbs of substance emission different from the other subclasses of verbs of emission?" will be discussed in chapter 9 .

The relevant outcome of this chapter is twofold: first, it has been shown that the gradable property is an attribute of an implicit argument of the verb. In a decompositional structure, verbs of emission are usually represented as shown in (85). The implicit emittee argument is not included in this representation but it is crucial for degree gradation as the gradation scale is not lexicalized by the verb but retrieved from the conceptual knowledge associated with the implicit emittee argument. Hence, an appropriate decomposition has to go beyond event structure templates. A richer lexical 
decomposition has partially been presented in this chapter by explicating the attributes that link the gradable property to the eventuality.
a. bleed: do'(x, bleed'(x))
b. drone: do' $\left(\mathrm{x}\right.$, drone' $\left.^{\prime}(\mathrm{x})\right)$

Second, verbs that belong to the same semantic class and also to the same aktionsart class can differ with regard to degree gradation. Two clear examples are the verbs represented in (85). Bleed as well as drone are verbs of emission and activity predicates. Therefore, the event structural representation is the same for both. With regard to degree gradation there is a crucial difference between both, which does not, and cannot follow from their event structural representation. Also bleed shows an interaction of grammatical aspect and degree gradation, drone does not. This indicates that there is a crucial, maybe also grammatically relevant, difference between both verbs, which is not captured by their event structural representation. 